\title{
Serovars, auxotypes, and plasmid contents of PPNG strains from outbreak in Amsterdam
}

\author{
M C ANSINK-SCHIPPER, ${ }^{*}$ S M BYGDEMAN,† B vAN KLINGEREN, \\ E G SANDSTRÖM§
}

From the *Municipal Health Service, Amsterdam, the Netherlands, the $†$ Institution of Clinical Bacteriology, Huddinge University Hospital, Karolinska Institute, Stockholm, Sweden, the $¥$ National Institute of Public Health, Bilthoven, the Netherlands, and the §Department of Venereology, Södersjukhuset, Karolinska Institute, Stockholm, Sweden

SUMMARY The first outbreak of penicillinase producing strains of Neisseria gonorrhoeae (PPNG) in Amsterdam in 1981-2 was caused mainly by African strains carrying the 24 megadalton transfer plasmid $\left(\mathrm{Afr}^{+}\right)$that were non-requiring (NR) and inhibited by phenylalanine (phen $\left.{ }^{i}\right)$, but African strains without the transfer plasmid $\left(\mathrm{Afr}^{-}\right)$that were $\mathrm{NRphen}{ }^{\mathrm{i}}$ and $\mathrm{Afr}^{+} \mathrm{NR}$ strains were also found.

Serological classification, using two monoclonal antibody systems, showed that three main serovars (Ae/Av, Aedih/Arst, and Bacejk/Brpyust) could be distinguished in these PPNG strains, which indicated exchanges of plasmids in these serovars. The serovar Ae/Av predominated in the $\mathrm{Afr}^{+}$and Bacejk/Brpyust in the $\mathrm{Afr}^{-}$strains.

\section{Introduction}

Van Embden et al found that, in almost all the $\beta$ lactamase (penicillinase) producing Neisseria gonorrhoeae (PPNG) strains isolated in Amsterdam in 1976-9, resistance to penicillin was encoded for by a 4.5 megadalton plasmid. ${ }^{1}$ Most of these isolates also carried a 24 megadalton transfer plasmid. Sporadic isolates, most of which were imported from west Africa, carried a smaller 3.3 megadalton resistance plasmid. The number of patients infected with PPNG strains started to increase in October 1980 and reached a peak in January 1981. Until October 1980 no strain harbouring the 3.3 megadalton plasmid had been found to carry the transfer plasmid (Afr ${ }^{-}$strains). Of 54 PPNG strains isolated in October 1980 and February to March 1981 and analysed, however, 38 harboured the 3.3 megadalton plasmid in conjunction with the 24 megadalton plasmid ( $\mathrm{Afr}^{+}$strains). $^{2}$ The penicillin resistance was transferable to Escherichia coli, which indicated that the 3.3 megadalton plasmid

Address for reprints: Dr M C Ansink-Schipper, Municipal Health Service, PO Box 20244, 1000 HE Amsterdam, the Netherlands Accepted for publication 26 September 1986 was transferable when it coexisted with the 24 megadalton plasmid.

As the number of infections with PPNG strains in Amsterdam had increased steadily, ${ }^{3}$ the Public Health Laboratory introduced routine auxotyping of the isolates in March 1982, ${ }^{4}$ and the National Institute of Public Health started measuring plasmid profiles in April 1981.5

From March 1981 to September 1982, $341 \mathrm{Afr}^{+}$ non-requiring (NR) and inhibited by phenylalanine (phen ${ }^{\mathrm{i}}$ ) strains, $26 \mathrm{Afr}^{+} \mathrm{NR}$ strains, and $106 \mathrm{Afr}^{-} \mathrm{NR}$ phen ${ }^{i}$ strains were isolated. ${ }^{4}$ These 473 strains constituted $65 \%$ of the 729 PPNG strains isolated in Amsterdam during this period. Only nine $\mathrm{Afr}^{+}$and two Afr- strains belonged to other auxotypes. We undertook serological classification of a representative sample of the $473 \mathrm{NR}$ strains into serovars to analyse further the outbreak of PPNG strains.

\section{Materials and methods}

PPNG STRAINS

We included in the study $208(61 \%)$ of the $341 \mathrm{Afr}^{+}$ NR phen ${ }^{\mathrm{i}}$ PPNG strains, 99(93\%) of the 106 Afr $^{-}$NR phen ${ }^{\mathrm{i}}$ strains, and all $26 \mathrm{Afr}^{+} \mathrm{NR}$ strains isolated in Amsterdam in March 1981 to September 1982. 
TABLE Serovars of 333 non-requiring (NR) penicillinase producing strains of Neisseria gonorrhoeae (PPNG) with African type 3.3 megadalton plasmid related to coexistance with 24 megadalton transfer plasmid $\left(\mathrm{Afr}^{+}\right)$and inhibition by phenylalanine (phen $i$ )

\begin{tabular}{llll}
\hline \multicolumn{4}{c}{ No (\%) of strains classified as: } \\
\hline GS/Ph & Afr ${ }^{+}$ & & $A f r^{-}$ \\
serocombinations & NR phen & Afr $^{+} N R$ & NR phen \\
\hline Ae/Av & $172(83)$ & $26(100)$ & $4(4)$ \\
Aedih/Arst & $11(5)$ & & $15(15)$ \\
Bacejk/Brpyust & $21(10)$ & & $76(76)$ \\
Bacejk/Brpyut & & & $2(2)$ \\
Other & $4(2)$ & & $2(2)$ \\
Total & 208 & 26 & 99 \\
\hline
\end{tabular}

${ }^{*} \mathrm{Ph}$ supplied by Pharmacia Diagnostics, Uppsala, Sweden, GS supplied by Syva, Palo Alto, USA.

\section{METHODS}

Identification of $\beta$ lactamase production, auxanographic typing, and plasmid characterisation have been described previously. ${ }^{45}$ Serological classification into serovars was performed as described ${ }^{6}$ using two different sets of monoclonal antibodies , the GS antibodies (Syva, Palo Alto, USA) and the $\mathrm{Ph}$ antibodies (Pharmacia Diagnostics, Uppsala, Sweden).

\section{Results}

All $26 \mathrm{Afr}^{+}$NR strains and most $(172 / 208,83 \%)$ of the $\mathrm{Afr}^{+} \mathrm{NR}$ phen ${ }^{i}$ strains belonged to the WI GS/Ph serovar Ae/Av (table and figure) in contrast to only
4\% (4/99) of the $\mathrm{Afr}^{-}$NR phen ${ }^{\mathrm{i}}$ strains. The GS serovar Bacejk dominated in the $\mathrm{Afr}^{-}$strains $(79 \%$, 78/99), whereas only $10 \%$ (21) of the $208 \mathrm{Afr}^{+} \mathrm{NR}$ phen ${ }^{i}$ strains belonged to this GS serovar. The GS serovar Bacejk could be resolved into two $\mathrm{Ph} / \mathrm{GS}$ serovar combinations (table), of which Bacejk/Brpyust accounted for $76 \%$ (76/99) of the Afr $^{-}$strains and $10 \%(21 / 208)$ of the $\mathrm{Afr}^{+} \mathrm{NR}^{-}$phen $^{\mathrm{i}}$ strains. Aedih/Arst was represented by 5\% (11/208) of the Afr ${ }^{+}$strains and $15 \%(15 / 99)$ of the $\mathrm{Afr}^{-}$strains.

Only $2 \%(4 / 208)$ of the Afr ${ }^{+}$NR phen strains and $2 \%(2 / 99)$ of the $\mathrm{Afr}^{-}$NR phen ${ }^{\mathrm{i}}$ strains belonged to other serovars.

\section{Discussion}

Earlier studies showed that the outbreak of gonorrhoea caused by PPNG strains in Amsterdam in 1981 was caused mainly by $\mathrm{Afr}^{+} \mathrm{NR}$ phen ${ }^{\mathrm{i}}$ strains. $^{45}$ PPNG strains of the same type but without the transfer plasmid were also isolated during the same time, though in smaller numbers. ${ }^{4}$ Serological classification of all these PPNG strains showed that three main serovars could be distinguished, Ae/Av, Aedih/Arst, and Bacejk/Brpyust (table). In all, Ae/Av strains accounted for $202(61 \%)$ of the 333 tested PPNG strains isolated during the study period 1981-2. The serovar $\mathrm{Ae} / \mathrm{Av}$ dominated in $\mathrm{Afr}^{+}$strains, and Bacejk/Brpyust in Afr $^{-}$strains. Ae/Av NR phen ${ }^{i}$ strains with the 3.3 megdalton plasmid seemed to have a great ability to survive and be transmitted. This ability seemed to be greater in strains that also carried the transfer plasmid.

Two other PPNG outbreaks caused by Ae/Av strains have been reported; one in Sweden caused by $\mathrm{Ae} / \mathrm{Av}$ NR strains that infected 31 patients, including
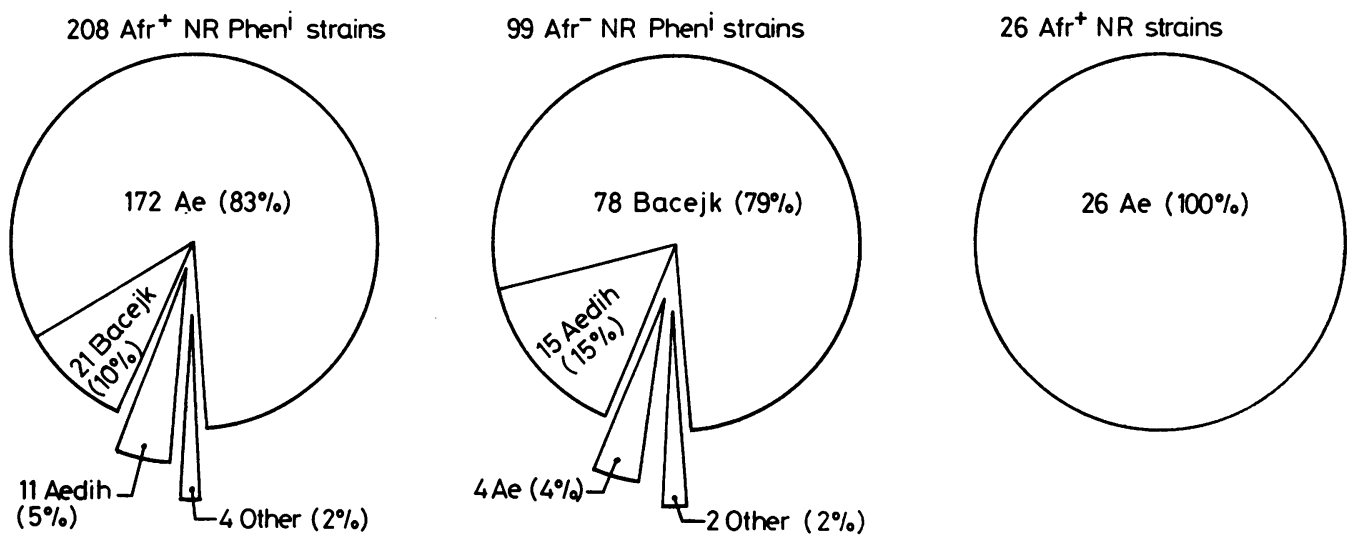

FIGURE Serovars (classified with GS monoclonal antibodies (Syva, Palo Alto, USA)) of 333 non-requiring (NR) penicillinase producing strains of Neisseria gonorrhoeae (African strains with $\left(A f r^{+}\right.$) or without (Afr ${ }^{-}$) 24 megadalton transfer plasmid and inhibited by phenylalanine (phen $\left.{ }^{i}\right)$ ) isolated in Amsterdam 1981-2. 
six prostitutes, ${ }^{7}$ and one in Canada caused by Asia ${ }^{+}$ $\mathrm{Ae}$ strains requiring proline and ornithine (Pro ${ }^{-}$ $\left.\mathrm{Orn}^{-}\right) .^{8}$

The Bacejk/Brpyust NR phen ${ }^{i}$ strains harbouring only the African type plasmid $\left(\mathrm{Afr}^{-}\right)$may, however, be more easily transmitted than those $\left(\mathrm{Afr}^{+}\right)$containing a coexisting 24 megadalton plasmid, or the 24 megadalton plasmid may have been introduced in strains of the NR phen ${ }^{i}$ phenotype late in the study period. $\mathrm{Afr}^{+}$strains had, however, been isolated by the start of the outbreak. The presence or absence of the 24 megadalton plasmid may confer a selective pressure that differentiates between strains of protein IA and protein IB serogroups.

$\mathrm{Ae} / \mathrm{Av}$ NR phen ${ }^{\mathrm{i}}$ strains with the Asian type plasmid were not identified in PPNG strains in Amsterdam during the study period, ${ }^{4}$ and the serovar $\mathrm{Ae} / \mathrm{Av}$ has not been identified in gonococcal strains from places like Bangkok or Singapore or in PPNG strains imported to Sweden from South East Asia (Bygdeman et al, unpublished data). The $\mathrm{Afr}^{+}$PPNG strains of the phenotype Ae/Av NR phen ${ }^{i}$ are therefore probably not the result of deletion of the 4.5 megadalton plasmid in Asia ${ }^{+}$strains but the acquisition of the 24 megadalton plasmid by $\mathrm{Afr}^{-}$strains. Aedih/Arst is the dominating WI serovar in South East Asia in both PPNG and non-PPNG strains, most of them being Pro ${ }^{-}$. NR Aedih/Arst PPNG strains have, however, been imported to Sweden from South East Asia, but not from Africa (Bygdeman et al, unpublished data). The $\mathrm{Afr}^{+}$Aedih/Arst strains that caused the PPNG outbreak in Amsterdam may therefore have originated from Asia ${ }^{+}$PPNG strains.

The presence of the transfer plasmid increases the ability of the $\mathbf{R}$ plasmid to disseminate, as the transfer plasmid is capable of mobilising the nonautotransmissible $\mathbf{R}$ plasmid into other gonococci. ${ }^{9}$ The number of different gonococcal strains, however, as judged by the number of serovars, was comparable in $\mathrm{Afr}^{+}$and $\mathrm{Afr}^{-}$strains.

Hendry and Dillon suggested that phenylalanine sensitive cells may promote replication or transmission of the 3.2 megadalton plasmid. ${ }^{10}$ This might explain why only one serovar (Ae/Av) was seen in the Afr ${ }^{+}$NR strains, whereas five different serovars were found in the $\mathrm{Afr}^{+}$NR phen ${ }^{\mathrm{i}}$ strains.

Plasmid profile assessment, auxanographic typing, and serological classification into serovars contribute to our understanding of the epidemiology, biological properties, and evolution of $\beta$ lactamase producing gonococci.

This work was supported by a grant (No 28-892) from the "Praeventiefonds" of the Netherlands.

We thank mesdames E C Gillenius, M H Huikeshoven, $M$ Dessens-Kroon, and $\mathbf{M}$ Verheuvel and $\mathbf{M r} \mathbf{R}$ Woudstra for their skilful technical assistance, Dr H G Ross for her clarification of the English, and Mrs W M Maruanaya for typing the manuscript.

\section{References}

1. Embden JDA van, Klingeren B van, Dessens-Kroon $\mathbf{M}$, Wijngaarden $\mathbf{L}$ van. Penicillinase-producing Neisseria gonorrhoeae in the Netherlands; epidemiology and genetic and molecular characterization of their plasmids. Antimicrob Agents Chemother 1980;18:789-97.

2. Embden JDA van, Klingeren $\mathbf{B}$ van, Dessens-Kroon $\mathbf{M}$, Wijngaarden $L J$ van. Emergence in the Netherlands of penicillinase producing gonococci carrying "Africa" plasmid in combination with transfer plasmid. Lancet 1981;i:938.

3. Coutinho RA, Schoonhoven FJ, Ansink-Schipper MC, et al. De verspreiding van penicillinase vormende gonokokken in Amsterdam. Ned Tüdschr Geneeskd 1982;126:221-3.

4. Ansink-Schipper MC, Huikeshoven MH, Woudstra RK, de Koning GAJ, Tio D. Epidemiology of PPNG infections in Amsterdam. British Journal of Venereal Diseases 1984;60:238.

5. Klingeren $\mathbf{B}$ van, Wijngaarden $\mathbf{L}$ van, Dessens-Kroon $\mathbf{M}$, Embden JDA van. Penicillinase producing gonococci in the Netherlands in 1981. J Antimicrob Chemother 1983;11:1520.

6. Bygdeman SM, Gillenius EC, Sandström EG. A comparison between two different sets of monoclonal antibodies for the serological classification of Neisseria gonorrhoeae. In: Schoolnik GK, Brooks G, Falkow JS, Knapp JS, McCutchan A, Morse S, eds. The pathogenic neisseriae. Proceedings of the fourth international symposium. Washington DC: American Society of Microbiology, 1985;31-6.

7. Ramstedt KM, Hallhagen GJ,Bygdeman SM, et al. Serological classification and contact-tracing in the control of microepidemics of $\beta$ lactamase producing Neisseria gonorrhoeae. Sex Transm Dis 1985;4:209-14.

8. Dillon JR, Pauzé M, Gould R, Sutherland R, Romanowski B Penicillinase producing Neisseria gonorrhoeae with Pro Orn ${ }^{-}$ WI Asia phenotype Lancet 1986; : $10 B-4$.

9. Sox TE Mohammed W,Blackman E Biswas G Sparling PF Conjugative plasmids in Neisseria gonorrhoeae.J Bacteriol 1978;134:278-86.

10. Hendry AT, Dillon JK .Growth inhibition of Neisseria gonorrhoeae isolates by 1-phenylalanine and its analogues in defined media .Can J Microbiol 1984;30:1319-25. 